\title{
Democracia Liberal: uma novidade já desbotada entre jovens
}

\author{
Renata Florentino \\ Mestranda do Programa de Sociologia da \\ Universidade de Brasília
}

\begin{abstract}
Resumo Este artigo busca mostrar a relação da juventude brasiliense com a política institucional, revelando o que está por trás da rejeição aos políticos profissionais e às instituições que ocupam. Em vez de estereotipar a postura crítica destes e destas jovens, sem antes analisar serenamente o contexto em que essa crítica surge, procurou-se mostrar o lugar de fala, a arena política em que surge essa crítica. Nessa arena, encontra-se uma democracia institucionalizada, com eleições estáveis, mas que não corresponde às expectativas que foram geradas com a sua implementação, junto com uma população bem informada e impactada por ações governamentais ou a ausência destas. Sem louvores ou reprovações, há que se perguntar se esta descrença da política institucional revela apenas uma desconexão de mundos ou a abertura de espaço para o surgimento de novas formas de organização política. O artigo trabalha com dados da PNAD 2005 e o Índice de Desenvolvimento Juvenil da UNESCO sobre a caracterização da juventude de Brasília e dados do TSE, sobre o alistamento eleitoral facultativo entre jovens.
\end{abstract}

Palavras-chaves: Brasília, Juventude, Participação Política, alistamento eleitoral

Abstract: This article intends to analize the relationship between the city of Brasília's youth and the institutional politics. We show what is behind the rejection to professional politicians and to the institutions they control. Instead of stereotipyze the critical behavior of the youth, we first analyze the context where this refusal takes place. We find an established democracy, with stable elections, but not corresponding to the expectations created during its implementation, added to a population that is well informed about the youth, it is necessary to ask if this lack of trust on institutional politics shows disconected worlds or a opened space to the emergence of new forms of political organization. This article is based on 2005 PNAD (National Research by Housing sample) data and the Youth Development Index of UNESCO, to describe the city of Brasilia youth, and on Electoral Supreme Court, about youth voting registering.

Keywords: city of Brasilia, Youth, Political Participation, electoral registration 
OPINIÃO PÚBLICA, Campinas, vol. 14, no 1, Junho, 2008, p.205-235.

Este estudo analisa aspectos da relação com a política institucional da juventude brasiliense, por esta ser a primeira geração nascida e criada após a redemocratização, num espaço simbólico que é Brasília, capital da República ${ }^{1}$. Essa temática suscita especial interesse em razão da imagem que foi construída de uma juventude alienada, despolitizada e desinteressada, reproduzida tanto pela mídia como por textos acadêmicos, ainda mais reforçada no caso de Brasília. Nesta reflexão, propõe-se um confronto entre o conhecimento empírico e esse tipo de formulação calcada em pensamentos morais ao analisar a adesão de determinados grupos sociais ao sistema político vigente.

Especialmente no campo da Ciência Política, há uma tradição de pensamento que tende a valorizar a relação de determinados grupos sociais com a política institucional, classificando positivamente o perfil urbanizado de camadas médias, de alta escolaridade e com fácil acesso a informações (LIPSET, 1987), enquanto grupos sociais de perfil menos elitizado freqüentemente são classificados como massa de manobra, mais suscetíveis a manipulações por parte dos políticos, menos condizentes com uma moderna democracia. O perfil de cidadãos "esclarecidos" chega quase a ser explicitamente recomendado e desejado pela literatura como o que mais se adequaria ao sistema político contemporâneo, dada a convicção da evolução positiva (e forte) entre a escolaridade, informação, interesse e participação. A rejeição às instituições políticas teria origem, supostamente, nos grupos sociais de perfil menos esclarecido, que não compreenderiam seu funcionamento e importância (DOWNS, 1957).

No caso brasiliense, a relação estaria incompleta, faltaria ainda um passo a ser dado. A evolução escolaridade, informação, interesse e participação não existiria plenamente, sendo retida no acesso a informações, mas sem que isso despertasse o interesse e a motivação necessária para participar. Entretanto, no decorrer dos últimos anos, uma série de dados apontava para outro caminho, especialmente, mas não só, dentro da juventude brasiliense. Além da alta escolaridade e do fácil acesso a informações, que seriam um contra-argumento à "alienação", vários outros indícios apontavam não para um afastamento alienado, mas para uma rejeição da política institucional e da classe dos políticos profissionais, embora não da política em si. Entre esses dados, ressaltam-se as pesquisas "Perfil da Juventude Brasileira", realizada em 2004 pelo Instituto Cidadania, e a pesquisa "Juventude Brasileira e Democracia", realizada pelo Instituto Brasileiro de Análises Econômicas e Sociais (IBASE) e Instituto Pólis em

\footnotetext{
1 Parte deste trabalho já foi apresentada como comunicação oral no II Simpósio Internacional da Juventude Brasileira, realizado em Porto Alegre, novembro de 2006. Agradeço os comentários dos participantes do GT "Políticas Públicas", que foram incorporados na análise aqui feita. Agradeço também a leitura crítica feita por Luis Felipe Miguel e Maria Francisca Pinheiro Coelho.
} 
2005, que mais tarde vieram a ser corroborados pelo levantamento do Tribunal Superior Eleitoral sobre o alistamento eleitoral facultativo de jovens de 16 e 17 anos nos pleitos de 2002 e 2006.

Enquanto essas pesquisas apontam o descrédito da política e dos políticos, procura-se aqui mostrar que, entre esses jovens, há uma visão crítica sobre os limites da política institucional. Esse encontro de opiniões refuta a tese de que a não-ação política é simplesmente resultado direto da alienação. A não-ação pode revelar também uma crítica, ainda que elaborada apenas no nível do imaginário, que pode tanto atrair o jovem para a política, para transformá-la, como pode afastá-lo, sem por isso desvalorizar suas percepções críticas relacionadas à política. A crítica pode estar tanto presente na ação política engajada, como na ausência dela, sem que se deva afirmar a priori que uma postura é valorativamente superior à outra.

\section{O futuro da nação}

Seriam os jovens a vanguarda que transformará o país? A geração que recebe e trata de transmitir a herança cultural recebida já pronta da sociedade? Essas visões, que vêm de correntes ideológicas distintas, se encontram no momento em que colocam uma carga, uma expectativa, enunciam um papel social a ser cumprido pelas novas gerações. Com essas expectativas, constroem-se ideais e modelos de juventude. Entretanto, qual é a inserção real dos jovens nas sociedades contemporâneas? O que pensam e o que esperam? Alguns dados apontam uma rejeição quanto a assuntos ligados à política institucional significativamente acima da média nacional para o Distrito Federal.

É comum, na literatura política, atribuir a falta de interesse pela política institucional a questões ligadas à alienação e desinformação: como um cidadão não consegue constituir determinado diálogo com o mundo, torna-se, portanto, incapaz de entendê-lo em profundidade. Essa abordagem é ainda mais forte quando se trata do engajamento político das gerações jovens atuais, comparado a passadas (mito áureo de 68), como percebido por Irene Cardoso: "A identificação das gerações posteriores com o mito da geração dos anos de 1960 (...) indica um aprisionamento das gerações mais jovens pela imagem de uma identidade heróica da geração anterior" (CARDOSO, 2005, p.103).

Além da alienação, vários fatores podem levar a uma rejeição da política. Pretende-se mostrar quais podem ser esses fatores e contribuir para repensar 0 mito de massa homogeneamente alienada e manipulada e explicitar que existe também a rejeição crítica da política, solidamente elaborada no nível do imaginário social da juventude. O contraste entre uma juventude idealista e uma carente de 
OPINIÃO PÚBLICA, Campinas, vol. 14, no 1, Junho, 2008, p.205-235.

ideais e causas, entre uma engajada e outra apática, será evitado. Dessa maneira, pode-se buscar mais livremente o objeto deste texto, a juventude brasiliense e seu imaginário social ligado à política. O caso de Brasília parece ser a explicitação extremada do fenômeno constatado em outras pesquisas sobre a relação da juventude com a política institucional (MÜXEL, 1997). Os dados sugerem que "não são os jovens que desconhecem a relevância da política, mas antes a forma predominante de se fazer política no país não os reconhece como interlocutores, gerando em muitos deles indiferença ou aversão" (ABRAMO e VENTURI, 2000, p.5).

É interessante perceber como se dá essa visão da política institucional na geração jovem brasileira atual, precisamente por ser a primeira geração do período de construção da democracia. Cabe então perceber as novas formas e temas pelos quais os jovens se mobilizam na esfera pública, que também podem apontar para o quadro de crise das formas tradicionais de participação e socialização política de modo geral. Assim, busco perceber o que é externalizado pelos jovens de Brasília em relação à política institucional, e, principalmente, como essa mensagem é externalizada. Isso revela muito dos jovens, de seu imaginário e, muitas vezes, da própria política.

Há algumas elaborações conceituais que são a base deste artigo, e uma área conexa que transmite interpretações que vão dando a maleabilidade necessária para perceber o fenômeno estudado. Dentre essas palavras, todas cheias de valorações, estão: juventude, alienação, apatia, ação política, partidos políticos, representação e participação.

“A juventude não é progressista nem conservadora por índole, porém, é uma potencialidade pronta para qualquer nova oportunidade ${ }^{2}$

(MANNHEIM, 1968, p.73)

Esse trecho da obra de Karl Mannheim, retirado de um texto seu da década de 1920, aponta um enfoque metodológico essencial para trabalhar a categoria da juventude: com base nele, pode-se evitar o lugar comum de se analisar jovens e movimentos juvenis tendo como ponto de referência básico o modelo de ativismo e participação que marcou a geração de 1968.

Dentro da abordagem política, os ângulos pelos quais a juventude é colocada em análise geralmente focam na sua dimensão de agente transformador e propositor de transformações, como sujeito capaz de introduzir mudanças reais na sociedade (FORACCHI, 1965, p.172). Nessa abordagem, os jovens são vistos como a possibilidade de renovação moral das sociedades. No Brasil, os discursos de

2 Grifo da autora. 
políticos populistas sobre os jovens e estudantes, desde os anos $1930^{3}$, reproduziam e estimulavam o mito da juventude progressista, que encontrava eco mesmo no discurso de líderes estudantis, que se acreditavam incumbidos de uma "missão" salvacionista.

Um ponto importante, que se faz presente nesse debate, é o enfoque geracional desses estudos. Há a disputa por duas visões. Uma, geralmente mais tradicional, da juventude como responsável pela reprodução da herança cultural de uma sociedade, e aí a preocupação com suas posturas de cunho político, para que ocorram dentro de um padrão esperado. Outra, a visão de que a juventude é obrigatoriamente a energia revitalizante de uma sociedade, ou seja, tem a responsabilidade não de reproduzir, mas de questionar e transformar algumas condições sociais de seu grupo ${ }^{4}$. Há elaborações com tons quase de convocatória direcionado aos jovens e a quem tem acesso a seus grupos, solicitando que este "recurso" social não seja desperdiçado (MELUCCI, 1997).

Nas duas visões, é esperado um papel da juventude, são criadas expectativas sobre suas ações, sem que, antes, haja espaço para que esse grupo possa se colocar em posição de sujeito de seus anseios e, conseqüentemente, suas ações. Nesse trabalho, há uma preocupação de tentar ao menos captar quais seriam esses anseios. Como constatou Helena Abramo em seu trabalho:

“... se produziu uma espécie de 'fixação' do modelo ideal do comportamento juvenil nos movimentos da década de 60. (...) É a partir dessa ótica que a geração jovem mais recente aparece principalmente marcada pela negatividade, pela ausência da capacidade da reflexão crítica da ordem social, pela passividade em relação aos valores e práticas sociais inscritas nas tendências sociais da época; essas ausências revelariam um desvio, uma traição da própria essência da condição juvenil" (ABRAMO, 1994, p. xiii).

Outra ocorrência de "juventricismo" ocorre em estudos mais recentes, de inspiração pós-moderna, ao tratar da boemia juvenil, da transgressão elitizada, de "estilos de vida" associados à juventude, que ganharam o tratamento de "culturas juvenis". Ao tentar responder à demanda desse segmento por uma maior inserção social, tentou-se superar a idéia de que a juventude seria apenas uma etapa de socialização e preparação para a vida adulta, constituindo um momento em si, sem precisar estar sempre relacionado ao momento da maturidade. Por mais que

\footnotetext{
${ }^{3}$ A criação da UNE (União Nacional dos Estudantes) em 1937, inicialmente estimulada pelo governo Getúlio Vargas, talvez seja um dos casos mais claros, além de própria propaganda da entidade enquanto protagonista de campanhas como "O Petróleo é Nosso" e a "Campanha em Defesa do Patrimônio Territorial e Econômico", por exemplo.

${ }^{4}$ Um dos textos mais conhecidos desta linha é o "Jovem Radical" de Octavio lanni (1969).
} 
OPINIÃO PÚBLICA, Campinas, vol. 14, no 1, Junho, 2008, p.205-235.

responda a uma demanda efetiva de reconhecimento de grupos juvenis, essa abordagem ainda guarda elementos de um olhar externo, um olhar adulto sobre seu objeto de pesquisa. Há que se perguntar sobre a não existência de uma categoria de análise da "cultura adulta", ou "cultura idosa", por exemplo (MÜLLER, 2004; 2006). A diversidade de estilos de vida experimentados pelas gerações jovens de hoje é muito mais reflexo de uma sociedade que guarda em si diversos estilos múltiplos de existência social do que algo diretamente relacionado à idade das pessoas, ocasionado por algum determinismo etário.

Entretanto, essa explicação baseada na existência de uma "modernidade reflexiva" é muito mais recorrente em estudos sobre sociedades em geral que sobre as ditas "culturas juvenis", que se tornaram um segmento exótico para observação. A contribuição desta abordagem é evitar a homogeneização ao analisar os segmentos juvenis, para não cair na construção de um "tipo ideal" jamais encontrado na realidade. A condição juvenil é e era, ao longo da "modernidade" e contemporaneidade, uma condição polêmica e por vezes indefinida, fruto da contradição posta e reposta entre instituições sociais e possibilidades de autonomia dos jovens. Esta concepção contraditória da condição juvenil na verdade pode ajudar a compreender as nuances das continuidades e descontinuidades entre as rebeldias juvenis do século XX e as do início do século XXI.

\section{Ação Política}

Intencionalmente, este trecho se intitula "ação política" embora trate mais especificamente da literatura sobre "alienação" e "apatia". Essa denominação ocorre em razão da adoção da abordagem weberiana sobre a ação, que considera que a não-ação é também considerada uma ação social, na medida em que lhe é atribuído um sentido, uma razão para sua ocorrência. Partimos deste pressuposto e consideramos a rejeição à política como uma opinião, na medida em que é uma ação escolhida entre outras ${ }^{5}$. Trata-se mais da condição de "alheamento" do que de "alienação".

O termo "alienação" é empregado em variados contextos, sendo que há um amplo debate sobre o conceito de alienação e sua importância no conjunto dos escritos de Marx. Para Louis Althusser, por exemplo, trata-se de um tema de juventude, abandonado na obra madura de Marx, quando já fora enterrado "o mito filosófico (teórico) do homem" (ALTHUSSER, 1965, p.203). Independentemente desta polêmica, "alienação" aparece como um dos conceitos centrais do marxismo ao longo do século XX.

\footnotetext{
${ }^{5} \mathrm{O}$ exemplo mais comum, embora polêmico, deste enfoque nos estudos eleitorais é o voto nulo.
} 
Na obra de Marx, a alienação se refere ao fato de que os serem humanos deixam de ser sujeitos para se tornarem objeto dos processos sociais. Embora a religião seja o protótipo deste processo (o homem se coloca na posição de criatura de um deus), é a alienação no trabalho que retém a atenção de Marx. Em outras palavras, "a alienação significa a incapacidade de conectar, ao nível cognitivo, a atividade individual com a produção da realidade social e econômica" (MIGUEL, 1999, p.179). A partir daí, torna-se possível identificar uma alienação especificamente política, traduzida pelo desconhecimento e pela não-participação nas atividades políticas. O mundo da política se apresenta como afastado, inatingível; as regras sociais aparecem como algo externo, algo que se impõe às pessoas, e não como o fruto da interação de mulheres e homens na sociedade.

Assim, a alienação política - aquilo a que se refere, em geral, o uso cotidiano da palavra - se aproxima da temática da "apatia". Antes de condenar os "alienados" ou "apáticos" com base num modelo normativo de "bom cidadão", como muitas vezes ocorre, convém observar que existem razões empíricas que motivam este comportamento, uma vez que as estruturas do campo político são efetivamente excludentes e a maior parte das iniciativas de intervenção se mostram, de fato, fadadas ao fracasso. Estas seriam possíveis causas da apatia política: a alienação, o sentimento de impotência, o boicote ao sistema político e até mesmo a satisfação com este (HUNTINGTON, 1975). Pode-se dizer que, na verdade, algumas das motivações para a apatia política são também as motivações para o ativismo político (RAMOS, 2001), à exceção do sentimento de impotência.

Para que se cobre certa atuação política, há que se perguntar qual é a real abertura a mudanças sociais provocadas por grupos subalternos nos sistemas políticos vigentes, visto que até mesmo as preferências eleitorais - arena de participação tida como principal nas democracias liberais - não vêm se traduzindo em mudanças políticas desejadas. Sartori (1994) afirma que as pessoas não estão envolvidas por não terem a competência ou o interesse suficiente para manifestar escolhas. Mesmo que se concordasse com os pressupostos de sua análise, valeria questionar: o que ocorre com as pessoas que possuem a competência e o interesse para se envolverem em questões políticas?

Um ponto importante é que para responder a esta indagação não basta focalizar no campo dos políticos profissionais, que seriam um exemplo bem sucedido para Sartori. Numa democracia concorrencial, com espaços institucionais limitados de ação política, há filtros que existem justamente para inibir a concorrência, e assegurar que determinados grupos participem mais que outros. De maneira mais clara: aqueles que não têm condições de se inserir no campo político institucional encontram-se em desvantagem para fazer com que suas posições tenham impacto na ação governamental. 
OPINIÃO PÚBLICA, Campinas, vol. 14, no 1, Junho, 2008, p.205-235.

\section{A cidade-capital}

Ao falar de qualquer aspecto da cidade de Brasília e sua região metropolitana, há que se tratar do discurso inaugural que construiu este espaço urbano, que esteve intensamente presente na agenda política do país de 1956 até os primeiros anos após a inauguração da cidade. Esta necessidade se coloca tanto pelo fato de Brasília ser efetivamente um marco do urbanismo das cidades planejadas como pelo fato de que nela, não só o espaço urbano, mas, fundamentalmente, o político influenciaram na constituição da cidade e de sua ocupação. A política é a razão de sua existência, o que impacta a cidade tanto positiva como negativamente.

O discurso de defesa da criação da cidade, dentro de um projeto desenvolvimentista que prometia refundar o país a partir de uma nova capital, revelou-se de certa maneira artificial. Mitos propagandeados de que a partir desta nova cidade haveria uma outra forma de fazer política sendo instituída logo foram dando espaço a enormes estímulos e benefícios para que os então deputados e funcionários públicos aceitassem sair do Rio de Janeiro (no seu auge de "cidade maravilhosa") e se mudassem para um canteiro de obras no meio do cerrado. E mesmo com estas concessões, a resistência foi tanta que até hoje algumas repartições estatais permanecem com sede no Rio (ou então contam com sedes duplas), a exemplo da Petrobrás, BNDES, Furnas, IBGE, IPEA, DNER e Casa da Moeda.

Sendo uma criação artificial, e não espontânea - caso de surgimento da maioria dos aglomerados urbanos no mundo - e tendo um discurso de criação que dava à cidade uma "missão" dentro de um projeto nacional, a cidade despertou em torno de si grandes expectativas, em grande parte frustradas pela instauração do regime militar três anos depois de sua inauguração. Prometida como uma etapa de um projeto de desenvolvimento, a cidade começou sua história condenada a ser não apenas um escritório matriz do Estado, mas uma sede do poder que se distanciava intencionalmente do povo brasileiro. O período em que a cidade começou a ser planejada, construída e habitada merece especial atenção. Pensada entre a ditadura de Vargas (1937-1945) e o regime militar (1964-1985), a cidade é um registro material de uma época de ideais que, mesmo incompletamente, foram concretizados. Há quem diga que, com todas as imperfeições que traz a realidade empírica, morar em Brasília é um privilégio, pois não se mora numa cidade, se mora numa idéia, num registro da imaginação que teve espaço num breve período democrático.

Embora Brasília tenha cumprido importante papel, implementado com razoável êxito pelos militares, de contribuir para a integração regional do país dentro de seu interior - facilitado pela expansão da fronteira agrícola - a integração 
política da cidade com o país e com sua população teve seu início adiado para mais de 20 anos depois de sua inauguração. Em relação à integração regional, Brasília se firmou como pólo atrativo de imigrantes, vindo tanto dos estados limítrofes, como de outros estados do Nordeste. A primeira onda de imigrantes recebidos pelo planalto central foi constituída por aqueles que vieram a ser chamados de "pioneiros" ou "candangos", os desbravadores iniciais deste campo, que foram se instalando na cidade e forçando o projeto urbano inicial a contemplar as chamadas cidades-satélites. A permanente tensão entre a área planejada (e tombada como patrimônio histórico cultural pela UNESCO desde 1987) e as áreas que foram habitadas antes e depois da inauguração do centro urbano se torna ainda mais delicada devido ao estatuto constitucional desta Unidade Federativa, pois há impedimentos jurídicos sobre o reconhecimento destas cidades satélites enquanto municípios de fato. Seus administradores são nomeados pelo governador do Distrito Federal e grande parte dos equipamentos públicos (bibliotecas e hospitais, por exemplo) ainda se concentra no Plano Piloto, sem falar nos postos de trabalho do mercado formal.

"Os jovens nascidos ou criados na periferia - antes de tudo, devido à brutal e perversa diferença de renda - também polemizam sobre o significado da cidade, comparam-se aos do Plano Piloto e sentem-se discriminados por várias razões: pelo fato de morarem na periferia, pela sua aparência e vestuário, pelas dificuldades que isso impõe na busca de emprego e pela condição racial" (ABRAMOVAY, et al., 1999)

Esta tensão permanente da divisão territorial já resultou em projeto de emenda constitucional $^{6}$ que sugere a criação do Estado do Planalto Central, tornando apenas o Plano Piloto e seus arredores a capital Brasília e sugerindo Taguatinga como capital deste outro Estado, que englobaria também cidades do entorno, localizadas em Goiás e Minas Gerais.

Mais recentemente, a cidade vem se firmando na lógica da rotatividade de habitantes que vêm e vão em razão de seus contratos de trabalho, funcionários transferidos na maior parte das vezes, que garantem à cidade certos aspectos de uma cidade de "estrangeiros", de pessoas que se mudam para uma cidade onde não possuem vínculos familiares prévios, que por vezes moram só, e seus vínculos se formam fundamentalmente pelas relações de trabalho. A forte presença de famílias mononucleares e a fragilidade dos vínculos sociais são vistas por alguns

\footnotetext{
6 O projeto (PEC 00056/1996) é de autoria do ex-senador Francisco Escórcio (PMDB/MA). Há também um projeto de lei de autoria do deputado federal Alberto Fraga (PMDB/DF) que sugere um plebiscito para decidir sobre o assunto. (PL4680/2004).
} 
OPINIÃO PÚBLICA, Campinas, vol. 14, no 1, Junho, 2008, p.205-235.

pesquisadores como um cenário que desestimula a solidariedade entre os habitantes da cidade, ocasionando um individualismo urbano acentuado (NUNES, 2004).

Entretanto, há que se perguntar se, sob um aspecto complementar, essa ausência de vínculos sociais prévios não constituiria também numa maior liberdade e autonomia na forma dos indivíduos se apresentarem para o mundo, uma vez que as expectativas geradas em cima do comportamento de cada um são reduzidas. No centro desta análise está a relação entre o conceito de "performance" e "fachada" feita por Erving Goffman (1975). Goffman relaciona todos os elementos do atuar cênico em sua explicação: um ator atua em uma posição onde há o palco e os bastidores; há relação entre a peça e a sua atuação; ele está sendo visto por um público mas, ao mesmo tempo, ele é o público da peça encenada pelos espectadores, parte integrante de seu meio.

De acordo com Goffman, o ator social tem a habilidade de se posicionar, escolher uma postura para cada palco e sua peça, assim como o figurino que ele usará para cada público. O objetivo principal do ator é manter sua coerência e se ajustar de acordo com a situação. Isso é feito, principalmente, através da interação com os outros atores. Estando num palco onde são reduzidos os grupos sociais que constituem sua platéia, os atores podem, então, ter mais momentos de despimento de suas máscaras sociais. Há menos expectativas sobre eles.

Já uma análise das características socioeconômicas da população brasiliense revela outro perfil peculiar. Levando em consideração aspectos como escolaridade, renda e tipo de ocupação econômica, é possível ver grupos que são, internamente, altamente homogêneos embora, comparados entre si, revelem uma sociedade altamente hierarquizada, concentrando guetos de classe média (basicamente composta pelo funcionalismo público) e de pobreza e miséria (autônomos e desempregados). O elitismo exacerbado do Plano Piloto e as precárias condições de vida existentes em grande parte das cidades satélites do Distrito Federal e seu entorno oferecem um espelho das desigualdades sociais do país, variando do urbano desejado à urbanização realizada (NUNES, 2004). 


\section{As juventudes candangas}

A população jovem do Distrito Federal contabilizada pelo Censo 2000 era de 459.224 pessoas, dos 15 aos 24 anos, o que corresponde a cerca de $28 \%$ de sua população total. Para todos os outros anos, utilizaremos estimativas demográficas calculadas de acordo com informações obtidas no IBGE. Um índice criado pelo escritório da UNESCO no Brasil, inspirado no IDH, foi construído para analisar especificamente as condições de vida do segmento juvenil que se encontra na faixa dos 15 aos 24 anos, o chamado Índice de Desenvolvimento Juvenil. Por este índice, é possível observar em que medida os equipamentos públicos dão conta de responder às demandas desta população (WAISELFIEZ, 2004).

Os indicadores de base foram assim construídos:

- Analfabetismo: porcentagem de analfabetos na faixa de 15 a 24 anos em relação à população total da mesma faixa etária. Fonte: PNAD (Pesquisa Nacional por Amostra de Domicílios).

- Escolarização Adequada: porcentagem de jovens de 15 a 24 anos que freqüentam escola de Ensino Médio ou Superior em relação à população total da mesma faixa etária. Fonte: PNAD.

- Qualidade do Ensino: média estandardizada das escalas de proficiência da $8^{a}$ série do Ensino Fundamental e da $3^{a}$ série do Ensino médio, nas áreas de Língua Portuguesa e Matemática. Fonte: SAEB (Sistema de Avaliação do Ensino Básico).

- Mortalidade por Causas Internas: taxa de óbitos em 100.000 jovens de 15 a 24 anos, atribuídos a causas internas, segundo definição da Classificação Internacional de Doenças - CID-10. Fonte: SIM (Sistema de Informações sobre Mortalidade).

- Mortalidade por Causas Violentas: taxa de óbitos em 100.000 jovens de 15 a 24 anos, ocorridos por causas violentas (suicídios, acidentes de transporte e homicídios, segundo definição da Classificação Internacional de Doenças - CID-10. Fonte: SIM.

- Renda Familiar per capita: valor do rendimento mensal familiar dividido pelo número de membros da família dos jovens na faixa de 15 a 24 anos. Fonte: PNAD.

Esses seis indicadores foram combinados para estruturar os três índices parciais: de educação, de saúde e de renda, constituindo o Índice de Desenvolvimento Juvenil. A juventude do Distrito Federal aparece entre as cinco primeiras posições em praticamente todos os indicadores positivos (em relação aos indicadores da área de educação e renda; ficando em primeiro ou em segundos 
OPINIÃO PÚBLICA, Campinas, vol. 14, no 1, Junho, 2008, p.205-235.

lugares nos indicadores de base) na liderança em termos de qualidade de vida. A exceção é o alto índice de mortes por razões violentas. A posição geral do Distrito Federal no índice de desenvolvimento é a $2^{a}$ colocação (perde apenas para Santa Catarina), o que certamente caracteriza uma ampla oferta de serviços públicos que asseguram significativa qualidade de vida.

Um indicador que não é considerado por este índice, mas é essencial para a análise aqui empreendida, é o acesso a meios de comunicação, como TV, rádio, jornais impressos, e internet. Para sinalizar o alto acesso a meios de informação, pode-se ver a taxa de acesso à internet no Distrito Federal, que é de $41 \%$ da população acima de cinco anos com acesso nos últimos três meses à rede, enquanto a taxa nacional é de $21 \%$ (PNAD, 2005). Portanto, o meio de comunicação mais elitizado atualmente atinge quase a metade da população.

\section{Geração democrata}

A escolha por trabalhar aproximadamente com a faixa etária de aproximadamente 15 a 25 anos foi feita não apenas com base no conceito padrão de juventude para pesquisas estatísticas, ou devido ao conceito de geração como tempo que leva para uma pessoa atingir a idade de montar seu próprio núcleo familiar. Esta escolha se deu pelo recorte do grupo etário que teria nascido já num regime assumidamente democrático, que oferece certas vivências e oportunidades de socialização política distintas. Aqui, o conceito de geração, no sentido de compartilhamento de certas experiências, de construção de referências comuns foi o determinante (MANNHEIM, 1968).

Tem-se como referência os seguintes marcos históricos como pontos de partida para o regime democrático: eleições parlamentares multipartidárias (1982), o movimento pelas Diretas Já (1984), a posse de um presidente civil (1985), a promulgação da nova Constituição (1988), as eleições diretas para presidente (1989) e o impeachment do ex-presidente Fernando Collor de Mello (1992). Ou seja, os nascidos nesse período compõem não só uma faixa etária, mas também um grupo que teve sua inserção social num país que já contava com elementos institucionais que Ihes garantiu uma socialização política diferenciada das gerações anteriores. Por exemplo, a disciplina "Educação Moral e Cívica" não fazia mais parte do currículo obrigatório das escolas"; já havia legislação que garantia a livre associação civil, inclusive para grêmios estudantis; a televisão e demais meios de comunicação já veiculavam propaganda política de diversos partidos; não havia mais censura em meios de comunicação ou na produção cultural. Esta geração

\footnotetext{
${ }^{7}$ Em algumas regiões esta disciplina se chamava OSPB - Organização Social e Política do Brasil. E, nas universidades, o nome também poderia ser EPB (Estudo de Problemas Brasileiros).
} 
cresceu já contando com certa oferta de espaços públicos a serem ocupados, incomparavelmente maior à oferta de qualquer geração anterior, garantida não só pela ausência da censura, como também pela crescente complexificação social do país ${ }^{8}$.

Além destes fatores, que são em grande parte comuns às juventudes de outras regiões brasileiras, há que se enfatizar que são fenômenos mais vivenciados ou acompanhados pela juventude do Distrito Federal na medida em que a política se faz presente no cotidiano da cidade (lendas urbanas e notícias de jornais locais são relacionadas à política nacional), e há também a questão da proximidade com a sede física dos órgãos públicos e entidades como partidos políticos, sindicatos nacionais etc.

Certamente, a coexistência no mundo por si só não assegura que um grupo faça parte da mesma geração (MANNHEIM, 1982). Há uma multiplicidade de fatores que condicionam as experiências sociais destes jovens, seja a classe social de sua família, se sua moradia é em área rural ou urbana, se pertence ou não a grupos étnicos marginalizados, seu gênero, opção religiosa, dentre tantos outros recortes possíveis. Entretanto, para esta análise, o peso desses fatores não será igualmente considerado. O recorte se guia pelo local de moradia e faixa etária.

\section{Falas}

Parte dos dados utilizados neste artigo foi tirada da pesquisa "Juventude Brasileira e Democracia" do IBASE/POLIS, que teve como objetivo conhecer os limites e possibilidades de participação em atividades políticas, sociais e comunitárias dos (as) jovens (15 a 24 anos) de oito Regiões Metropolitanas do país (Belém, Belo Horizonte, Brasília, Porto Alegre, Recife, Rio de Janeiro, São Paulo e Salvador), totalizando uma amostra de 8000 jovens no Brasil, sendo 600 jovens no Distrito Federal, entrevistados entre os meses de setembro e novembro de 2004.

A pesquisa foi realizada através de dois métodos: pesquisa de opinião (quantitativa) e grupos de diálogo (qualitativa), estes últimos baseados na metodologia Choice Work Dialogue Methodology ${ }^{9}$. Na região metropolitana de Brasília, a pesquisa foi coordenada por Ozanira Ferreira da Costa, doutoranda do Departamento de Serviço Social da UnB.

\footnotetext{
8 Neste ponto, é importante frisar que o Movimento Estudantil já não conta com a adesão unânime dos estudantes enquanto principal canal de atuação política. Antes de dizer que há uma crise de participação, entretanto, há que se perceber outras formas de atuação incorporadas aos movimentos sociais, sejam novidades temáticas como entidades que discutam raça e orientação sexual, sejam entidades com outros modelos de gestão, com menor número de associados e participação mais focada.

${ }^{9}$ Metodologia utilizada pelo Canadian Policy Research Networks (CPRN).
} 
OPINIÃO PÚBLICA, Campinas, vol. 14, no 1, Junho, 2008, p.205-235.

O modelo de amostragem utilizado foi o de conglomerados, aplicado em duas etapas. A seleção dos conglomerados (setores censitários do IBGE) na primeira etapa foi realizada com probabilidade proporcional ao tamanho, na qual a medida foi o número de jovens de 15 a 24 anos residentes nos setores. Na segunda etapa foram selecionados, dentro de cada setor censitário, dez jovens para serem entrevistados. O modelo de amostragem deu a cada jovem das Regiões Metropolitanas e Distrito Federal igual probabilidade de ser selecionado (a) para a amostra $2^{10}$.

Os grupos de diálogo foram estruturados da seguinte maneira: entre os previamente entrevistados por meio de questionário houve o convite para que continuassem participando da pesquisa, que foram posteriormente contatados. Ocorreram cinco encontros, com cerca de noventa jovens puderam "dialogar" sobre os seus pontos de vistas dos temas em questão. Os pressupostos do roteiro metodológico eram de que "a opinião não é formada individualmente, mas na interação com informações recebidas e com outras pessoas" (IBASE, 2005).

$\mathrm{Na}$ pesquisa realizada em Brasília, o Grupo de Diálogo teve o seguinte perfil: noventa jovens de dezenove cidades ou Regiões Administrativos do Distrito Federal com predominância absoluta de jovens da Ceilândia (dezenove), Santa Maria e Gama (nove jovens), e Sobradinho e Plano Piloto (oito jovens). No Plano Piloto, estão incluídos os jovens do Cruzeiro e do Lago Norte. A maioria é da classe C, com 42 jovens, seguidos das classes D/E, com 29 jovens, e das Classes A/B, com 19 jovens. Todos freqüentam ou freqüentaram a escola: 21 têm o ensino fundamental (incompleto ou completo), 55 o ensino médio (incompleto ou completo) e 14 o ensino superior. Entre os noventa jovens, 36 trabalhavam quando a pesquisa foi realizada.

As perguntas centrais dos Grupos de Diálogo questionavam:

1 Pensando na vida que você leva como jovem brasileiro (a), o que pode melhorar na educação, trabalho e nas atividades de cultura e lazer?

2 A partir das melhorias listadas, como vocês estariam dispostos (as) a participar para que elas se tornem realidade?

3 O que mais te preocupa no Brasil?

4 Que recado você daria para os governantes / políticos?

A segunda pergunta ofereceu três "tipos ideais" de participação para que os jovens escolhessem seu caminho:

${ }^{10}$ As explicações metodológicas baseiam-se no relatório do IBASE. 
FLORENTINO, R. Democracia Liberal: uma novidade já desbotada...

Caminho Participativo 1: Eu me engajo e tenho uma bandeira de luta “A participação política da juventude ocorre por meios que vão além do voto. Esse engajamento também se dá na atuação firme e direta em partidos políticos, organizações estudantis, conselhos, ONGs e movimentos sociais, ou seja, em instituições que organizam a sociedade e controlam a atuação dos governos."

Caminho Participativo 2: Eu sou voluntário (a) e faço a diferença "Jovens voluntários (as) ajudam a diminuir os problemas sociais. Realizam diferentes atividades tais como manutenção de escolas, recreação com crianças pobres e hospitalizadas, campanhas de doação de alimentos e diversas outras ações desse tipo."

Caminho Participativo 3: Eu e meu grupo: nós damos o recado "Os (As) jovens praticam e fortalecem o direito à livre organização. Eles (as) formam grupos culturais (esportivos, artísticos, musicais etc.), religiosos, de comunicação (jornal, página na Internet, fanzine etc.), entre outros, compartilhando idéias com outros (as) jovens."

\section{O contra exemplo}

O caminho 1 foi o que teve a menor adesão dentre os jovens brasilienses. Como ponto favorável, esta participação mais institucionalizada é vista pelos jovens como o caminho que leva diretamente ao governo. Destacaram a importância da participação política como a forma mais concreta de atingir seus objetivos.

Entretanto, os empecilhos para este tipo de ação política são vários: descrença nos políticos, vistos como incorretos; descrédito nos resultados das ações; compete com a necessidade de trabalhar e ganhar dinheiro. Os jovens também manifestaram a visão de que através dos movimentos políticos eles se tornam visíveis aos olhos da sociedade, embora grande parte não se veja nesse tipo de política, como se fosse algo muito distante de suas realidades.

Nesta avaliação, vale fazer uma relação com os dados da pesquisa quantitativa: para os jovens entrevistados, a maioria dos políticos não representa os interesses da população: $64,7 \%$ em nível nacional. No DF esse percentual atingiu mais de $80 \%$.

Os escândalos políticos e financeiros que pautaram o noticiário político nos últimos anos fortaleceram a perda de confiança dos cidadãos de modo geral, e não apenas dos jovens, em relação à classe política. Há certa sensação de nojo ao se referir a políticos profissionais. A pesquisa quantitativa aponta nacionalmente que 
OPINIÃO PÚBLICA, Campinas, vol. 14, no 1, Junho, 2008, p.205-235.

$65,6 \%$ - no Distrito Federal o percentual cai para 59\% - procuram se informar sobre política; $24,7 \%$ (no Distrito Federal $33,7 \%$ ) não procuram se informar. 0 fato de os jovens do Distrito Fderal terem a menor taxa de busca por informações do noticiário político ao mesmo tempo em que têm mais condições de fazê-lo é especialmente instigante. Pode significar tanto alienação como indicar que, mesmo sem buscar informações nos jornais, eles já dispõem de outros meios para receber as notícias, ou pode mesmo ser uma decisão, baseada num cansaço e overdose de notícias negativas.

Essa perda generalizada de credibilidade estabelece um tipo de ruptura dos laços que poderiam unir os jovens ao mundo político. Cada vez mais, o campo político é percebido como um mundo "paralelo", muitas vezes incompreensível, tornando difícil para os (as) jovens se identificarem e se situarem neste campo. Mesmo quando essa resistência à política profissional é visível à classe política, ainda não se vislumbram soluções, como aponta Helena Abramo:

"A maior parte dos atores políticos queixa-se da distância que os jovens têm demonstrado para com as suas proposições, bandeiras e formas de atuação, o que reflete, em primeiro plano, uma preocupação com a renovação de quadros no interior dessas organizações, mais do que em tratar e incorporar temas levantados pelos próprios jovens" (ABRAMO, 1997, p.27).

Dentro do Grupo de Diálogo, houve falas que argumentavam que o caminho da política institucional era efetivamente o caminho mais adequado para que se reivindicassem direitos sociais, mas os jovens não conseguiam se perceber fazendo política da maneira como é feita nas instâncias institucionais de deliberação.

"O descrédito na classe política e no sistema político foi outro ponto alto, deixando um clima de pessimismo diante das temáticas trabalhadas, sob o argumento de que [os jovens] não são ouvidos ou que governantes não cumprem suas promessas" (COSTA, 2005, p.19).

O caminho 2 foi visto nos Grupos de Diálogo do Distrito Federal como o melhor caminho para a realização do trabalho comunitário. Este caminho é o da "ação voluntária/ comunitária", entendida pelos jovens como fruto de uma ação coletiva. Os jovens são af favor desse caminho por ser o caminho mais rápido, pelo qual se pode agir por conta própria já que "o governo demora muito para resolver os problemas". Como obstáculos à participação, foram apontados que a experiência neste tipo de ação é um trabalho de ocupação, mas não tem as 
características necessárias para ser vista e valorizada profissionalmente, não podendo ser apresentada no currículo profissional, por exemplo; além de ser pouco eficiente para mudar a realidade de maneira estrutural.

O caminho 3 é visto como o da cultura. As vantagens de participar deste tipo de ação é que nela está uma oportunidade concreta de expressar suas idéias democraticamente. Para os jovens do Distrito Federal, o aspecto positivo desse caminho é que privilegia o trabalho em grupo desde o início. Pesam contra ele os fatos de que ações culturais não possuem força política, de que o governo não dá crédito a essas ações e as atividades afastam o jovem da escola por serem muito mais atraentes, reforçando a idéia de que a escola é uma obrigação maçante de ser cumprida. Este é o que tem maior aceitação no Distrito Federal e foi percebido como a forma mais genuína de organização da juventude, ainda que relacionado quase que estritamente a atividades de lazer. Outro aspecto valorizado nesse caminho foi a ação em grupos, que são vistos como possibilidades de formação e de conquista de visibilidade.

No Grupo de Diálogo foi perguntado: Que recado você mandaria para as pessoas que tomam decisão em nosso país? As principais respostas dos jovens do Distrito Federal foram:

- Para os governantes serem mais responsáveis;

- Darem mais atenção aos jovens;

- Combaterem a fome e a pobreza;

- Investirem em educação;

- Acabarem com a corrupção e

- Renovarem as formas de fazer política.

De acordo com o Relatório Final do IBASE/PÓLIS, o resultado do Grupo de Diálogo do Distrito Federal diferenciou-se muito dos demais também neste item, priorizando temas relacionados à política em relação às outras regiões. Esta observação reflete também o resultado da sistematização de termas abordados livremente dentro dos grupos, na qual assuntos ligados a política também tiveram uma presença mais forte no Distrito Federal do que nas outras regiões metropolitanas: 
OPINIÃO PÚBLICA, Campinas, vol. 14, no 1, Junho, 2008, p.205-235.

Tabela 1. Preocupação dos(as) jovens no Brasil segundo temas e ordem de incidência por região

\begin{tabular}{|c|c|c|c|c|c|c|c|c|}
\hline \multirow{2}{*}{$\begin{array}{c}\text { Temas/questões } \\
\text { mais recorrentes } \\
\text { nos Grupos de } \\
\text { Diálogo }\end{array}$} & \multicolumn{8}{|c|}{ Classificação da incidência nas RM e no DF } \\
\hline & Belém & $\begin{array}{c}\text { Belo } \\
\text { Horizonte }\end{array}$ & $\begin{array}{l}\text { Distrito } \\
\text { Federal }\end{array}$ & $\begin{array}{l}\text { Porto } \\
\text { Alegre }\end{array}$ & Recife & $\begin{array}{l}\text { Rio de } \\
\text { Janeiro }\end{array}$ & $\begin{array}{l}\text { São } \\
\text { Paulo }\end{array}$ & Salvador \\
\hline $\begin{array}{c}\text { Violência / Falta de } \\
\text { Segurança / } \\
\text { Criminalidade } \\
\end{array}$ & 2 & 1 & 2 & 1 & 1 & 1 & 2 & 1 \\
\hline $\begin{array}{c}\text { Trabalho/ Emprego } \\
\text { / Desemprego / } \\
\text { Falta de } \\
\text { oportunidade / } 1^{\circ} \\
\text { Emprego } \\
\end{array}$ & 3 & 2 & 1 & 1 & 3 & 2 & 1 & 2 \\
\hline Educação & 4 & 4 & 3 & 2 & 2 & 3 & 3 & 4 \\
\hline $\begin{array}{c}\text { Miséria / Pobreza / } \\
\text { Fome / } \\
\text { Desigualdade / Má } \\
\text { distribuição de } \\
\text { renda }\end{array}$ & 1 & 3 & 5 & 3 & 4 & 4 & 4 & 3 \\
\hline Saúde & / & / & / & 4 & / & 4 & / & / \\
\hline $\begin{array}{c}\text { Discrimação / } \\
\text { Racismo / } \\
\text { Preconceito } \\
\end{array}$ & 5 & / & / & / & I & I & I & / \\
\hline $\begin{array}{l}\text { Política / } \\
\text { Corrupção / } \\
\text { Descaso do } \\
\text { Governo com } \\
\text { jovens / Falta de } \\
\text { consciência dos } \\
\text { governnates }\end{array}$ & I & 5 & 4 & I & I & I & 5 & 5 \\
\hline Drogas & I & / & I & 5 & 5 & / & I & / \\
\hline $\begin{array}{c}\text { Sociedade/Valores } \\
\text { / Brasil / Situação } \\
\text { do povo }\end{array}$ & I & I & I & 5 & I & I & I & / \\
\hline
\end{tabular}

Fonte: IBASE/POLIS, 2005 


\section{Alistamento eleitoral}

Entre os dados "positivos" que o TSE divulgou em sua campanha de estímulo ao voto, como respostas às campanhas pelo voto nulo organizadas por eleitores descontentes com o sistema político, estava uma tabela que indicava que os jovens estavam animados com a democracia, ansiosos por vivenciar seu primeiro voto.

Tabela 2. Crescimento de eleitores entre 16 e 17 anos (2002-2006)

\begin{tabular}{|c|c|c|c|c|c|c|}
\hline \multicolumn{2}{|c|}{$\begin{array}{l}\text { Unidade } \\
\text { Federativa }\end{array}$} & \multirow{2}{*}{$\begin{array}{c}\text { Jovens com } \\
\text { título em } \\
2002 \\
\\
91.17\end{array}$} & \multirow{2}{*}{$\begin{array}{c}\text { Total de } \\
\text { eleitores na } \\
\text { UF em } 2002 \\
(\%) \\
0,8\end{array}$} & \multirow{2}{*}{$\begin{array}{c}\text { Jovens com } \\
\text { título em } \\
2006 \\
\\
149.18\end{array}$} & \multirow{2}{*}{$\begin{array}{c}\text { Total de } \\
\text { eleitores na } \\
\text { UF em } 2006 \\
(\%) \\
1,3\end{array}$} & \multirow{2}{*}{$\begin{array}{c}\text { Aumento no } \\
\text { número de } \\
\text { eleitores jovens } \\
\text { entre } 2002- \\
2006 \\
(\%) \\
63,6\end{array}$} \\
\hline $1^{\circ}$ & $\begin{array}{l}\text { Rio de } \\
\text { Janeiro }\end{array}$ & & & & & \\
\hline $2^{\circ}$ & Pará & 79.35 & 2,2 & 126.30 & 3,0 & 59,1 \\
\hline $3^{\circ}$ & São Paulo & 310.95 & 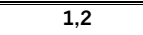 & 4993.75 & 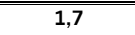 & 58,7 \\
\hline $4^{\circ}$ & Amazonas & 38.46 & 2,5 & 60.7 & 3,3 & 56,1 \\
\hline $5^{\circ}$ & Pernambuco & 107.86 & 2,0 & 168.05 & 2,8 & 55,7 \\
\hline $6^{\circ}$ & Alagoas & 40.63 & 2,5 & 62.30 & 3,3 & 53,3 \\
\hline $7^{\circ}$ & $\begin{array}{l}\text { Espírito } \\
\text { Santo }\end{array}$ & 37.07 & 1,7 & 56.33 & 2,4 & 51,9 \\
\hline $8^{\circ}$ & Ceará & 128.95 & 2,6 & 194.20 & 3,6 & 50,5 \\
\hline $9^{\circ}$ & $\begin{array}{l}\text { Minas } \\
\text { Gerais } \\
\end{array}$ & 206.32 & 1,6 & 307.45 & 2,2 & 49,0 \\
\hline $10^{\circ}$ & Amapá & 11.69 & 4,0 & 16.72 & 4,6 & 42,9 \\
\hline $11^{\circ}$ & Maranhão & 112.53 & 3,3 & 159.37 & 4,0 & 41,6 \\
\hline $12^{\circ}$ & Sergipe & 21.18 & 2,2 & 42.37 & 3,2 & 35,8 \\
\hline $13^{\circ}$ & $\begin{array}{l}\text { Santa } \\
\text { Catarina } \\
\end{array}$ & 70.15 & 1,8 & 94.90 & 2,2 & 35,2 \\
\hline $14^{\circ}$ & $\begin{array}{l}\text { Mato Grosso } \\
\text { do Sul }\end{array}$ & 31.98 & 2,2 & 42.74 & 2,7 & 33,6 \\
\hline $15^{\circ}$ & Rondônia & 25.99 & 2,9 & 34.58 & 3,5 & 33,0 \\
\hline $16^{\circ}$ & Bahia & 187.96 & 2,2 & 237.25 & 2,6 & 26,2 \\
\hline $17^{\circ}$ & $\begin{array}{l}\text { Rio Grande } \\
\text { do Norte } \\
\end{array}$ & 63.98 & 3,3 & 80.47 & 3,8 & 25,7 \\
\hline $18^{\circ}$ & Paraíba & 78.11 & 3,3 & 96.23 & 3,7 & 23,1 \\
\hline $19^{\circ}$ & Acre & 14.18 & 3,8 & 17.41 & 4,2 & 22,8 \\
\hline $20^{\circ}$ & Goiás & 74.29 & 2,2 & 91.21 & 2,4 & 22,8 \\
\hline $21^{\circ}$ & Paraná & 135.66 & 2,0 & 164.62 & 2,3 & 21,3 \\
\hline $22^{\circ}$ & Piauí & 73.14 & 3,9 & 87.48 & 4,2 & 19,6 \\
\hline $23^{\circ}$ & $\begin{array}{l}\text { Rio Grande } \\
\text { do Sul }\end{array}$ & 143.34 & 1,9 & 168.91 & 2,1 & 17,8 \\
\hline $24^{\circ}$ & Tocantins & 29.55 & 3,7 & 34.72 & 3,9 & 17,4 \\
\hline $25^{\circ}$ & Mato Grosso & 53.94 & 3,1 & 62.51 & 3,2 & 15,8 \\
\hline $26^{\circ}$ & Roraima & 8,61 & 4,1 & 9.61 & 4,1 & 11,6 \\
\hline $27^{\circ}$ & $\begin{array}{l}\text { Distrito } \\
\text { Federal } \\
\end{array}$ & 30.62 & 2,0 & 30.65 & 1,8 & 0,1 \\
\hline
\end{tabular}


OPINIÃO PÚBLICA, Campinas, vol. 14, no 1, Junho, 2008, p.205-235.

Na Tabela 2, é possível perceber que entre 2002 e 2006 houve um crescimento na procura por título de eleitor em praticamente todos os estados da federação. Entretanto, para se averiguar qual é exatamente o tamanho deste crescimento, é necessário calcular o percentual de títulos tirados em relação à população jovem que estava em condições de fazer esta opção, pois aí se tem o indicador adequado sobre o interesse pelas eleições (FREIRE \& MAGALHÃES, 2002, p. 22). Por exemplo, é registrado o aumento de $0,1 \%$ nos jovens brasilienses com título de eleitor. Mas, na verdade, no Distrito Federal ocorre um recuo e não crescimento, pois, se for considerado o aumento demográfico da população entre 16 e 17 anos, o crescimento de 0,1\% contabilizado de 2002 para 2006 não consegue nem mesmo manter o percentual de jovens eleitores alistados em 2002. Pela Tabela 3, a seguir, fica mais fácil perceber a relação entre o crescimento populacional e o alistamento eleitoral nesse período, o qual mostra uma queda relativa no Distrito Federal:

\section{Tabela 3 - Taxa de Alistamento e Dados da População Jovem de 16 e 17anos no Brasil por Ufs (2002- 2006)}

\begin{tabular}{|c|c|c|c|c|c|c|c|c|c|}
\hline UF & $\begin{array}{c}\text { Jovens 16- } \\
17 \text { anos } \\
\text { com título } \\
\text { em } 2002\end{array}$ & $\begin{array}{c}\text { População } \\
16-17 \text { anos } \\
2002\end{array}$ & \begin{tabular}{||c|} 
Taxa de \\
alistamento - \\
$\%$ em \\
relação ao \\
total 2002 \\
\end{tabular} & \begin{tabular}{|c} 
Jovens $16-$ \\
17 anos com \\
título em \\
2006
\end{tabular} & $\begin{array}{c}\text { População } \\
16-17 \text { anos } \\
2006\end{array}$ & \begin{tabular}{|c} 
Taxa de \\
alistamento - \\
$\%$ em \\
relação ao \\
total 2006 \\
\end{tabular} & $\begin{array}{c}\text { Variação \% } \\
\text { na pop. 16- } \\
17 \text { anos } \\
2002-2006\end{array}$ & \begin{tabular}{|c|} 
Variação \% \\
no número \\
de eleitores \\
jovens 2002- \\
2006 \\
\end{tabular} & \begin{tabular}{|l} 
Variação \% \\
na taxa de \\
alistamento
\end{tabular} \\
\hline $\mathrm{RR}$ & 8.610 & 10.508 & 81,9 & 9.615 & 15.968 & 60,2 & 52,0 & 11,7 & $-26,5$ \\
\hline AC & 14.181 & 19.670 & 72,1 & 17.418 & 31.535 & 55,2 & 60,3 & 22,8 & $-23,4$ \\
\hline DF & 30.621 & 79.154 & 38,7 & 30.658 & 98.938 & 31,0 & 25,0 & 0,1 & $-19,9$ \\
\hline RO & 25.994 & 43.347 & 60,0 & 34.588 & 69.435 & 49,8 & 60,2 & 33,1 & $-16,9$ \\
\hline PA & 79.357 & 201.893 & 39,3 & 126.300 & 290.023 & 43,5 & 43,7 & 59,2 & 10,8 \\
\hline MT & 53.941 & 109.384 & 49,3 & 62.510 & 113.763 & 54,9 & 4,0 & 15,9 & 11,4 \\
\hline AP & 11.698 & 23.437 & 49,9 & 16.722 & 29.762 & 56,2 & 27,0 & 42,9 & 12,6 \\
\hline $\mathrm{PI}$ & 73.143 & 137.705 & 53,1 & 87.481 & 140.734 & 62,2 & 2,2 & 19,6 & 17,0 \\
\hline TO & 29.559 & 57.458 & 51,4 & 34.729 & 57.357 & 60,5 & $-0,2$ & 17,5 & 17,7 \\
\hline RS & 143.346 & 370.262 & 38,7 & 168.916 & 365.726 & 46,2 & $-1,2$ & 17,8 & 19,3 \\
\hline GO & 74.296 & 203.757 & 36,5 & 91.216 & 203.268 & 44,9 & $-0,2$ & 22,8 & 23,1 \\
\hline PR & 135.665 & 387.540 & 35,0 & 164.623 & 377.514 & 43,6 & $-2,6$ & 21,3 & 24,6 \\
\hline PB & 78.115 & 154.390 & 50,6 & 96.237 & 148.690 & 64,7 & $-3,7$ & 23,2 & 27,9 \\
\hline AM & 38.463 & 108.396 & 35,5 & 60.074 & 130.490 & 46,0 & 20,4 & 56,2 & 29,7 \\
\hline SC & 70.158 & 217.534 & 32,3 & 94.909 & 224.662 & 42,2 & 3,3 & 35,3 & 31,0 \\
\hline MA & 112.538 & 297.620 & 37,8 & 159.372 & 312.232 & 51,0 & 4,9 & 41,6 & 35,0 \\
\hline $\mathrm{RN}$ & 63.987 & 128.019 & 50,0 & 80.476 & 115.610 & 69,6 & $-9,7$ & 25,8 & 39,3 \\
\hline BA & 187.963 & 648.750 & 29,0 & 237.259 & 564.316 & 42,0 & $-13,0$ & 26,2 & 45,1 \\
\hline MG & 206.327 & 735.378 & 28,1 & 307.452 & 745.652 & 41,2 & 1,4 & 49,0 & 47,0 \\
\hline$A L$ & 40.633 & 130.877 & 31,0 & 62.305 & 133.881 & 46,5 & 2,3 & 53,3 & 49,9 \\
\hline MS & 31.989 & 101.995 & 31,4 & 42.746 & 89.258 & 47,9 & $-12,5$ & 33,6 & 52,7 \\
\hline SE & 31.185 & 85.114 & 36,6 & 42.378 & 73.476 & 57,7 & $-13,7$ & 35,9 & 57,4 \\
\hline ES & 37.075 & 139.954 & 26,5 & 56.337 & 134.246 & 42,0 & $-4,1$ & 52,0 & 58,4 \\
\hline RJ & 91.171 & 492.528 & 18,5 & 149.180 & 504.696 & 29,6 & 2,5 & 63,6 & 59,7 \\
\hline CE & 128.956 & 350.075 & 36,8 & 194.202 & 326.788 & 59,4 & $-6,7$ & 50,6 & 61,3 \\
\hline SP & 310.950 & 1.405 .480 & 22,1 & 493.752 & 1.371 .393 & 36,0 & $-2,4$ & 58,8 & 62,7 \\
\hline $\mathrm{PE}$ & 107.863 & 369.444 & 29,2 & 168.050 & 320.041 & 52,5 & $-13,4$ & 55,8 & 79,8 \\
\hline Brasil & $\begin{array}{l}2.217 .784 \\
\end{array}$ & 7.007 .669 & 31,6 & 3.089.505 & 6.979.454 & 44,3 & $\begin{array}{l}-0,4 \\
\end{array}$ & 39,3 & 39,9 \\
\hline
\end{tabular}

Fontes: Tribunal Superior Eleitoral, dados divulgados em 2006. IPEA, a partir de dados do IBGE - Projeção da População 
Além do Distrito Federal, apenas os estados do Acre e Rondônia registraram queda na taxa de alistamento no voto facultativo entre jovens (última coluna da tabela). Vale observar, contudo, que no caso destes dois estados nortistas a queda na taxa de alistamento deve-se ao surpreendente crescimento da população nessa faixa de idade (nos dois casos acima de 60\%), provavelmente devido à imigração para estas localidades. Embora o Distrito Federal também registre crescimento populacional significativo, o fenômeno ocorre em uma proporção bem menor (25\%, comparável ao Amazonas e Amapá, UFs onde a taxa de alistamento subiu), caracterizando a queda na taxa de alistamento do Distrito Federal como caso particular no país.

No Distrito Federal, contamos com 79.154 jovens potencialmente eleitores para o pleito de 2002, e 98.938 para o pleito de 2006. Em 2002, de acordo com os dados do TSE, 30.621 jovens tiraram o título, cerca de $38,7 \%$ do total de jovens que estavam aptos a fazê-lo. Para o pleito de 2006, 30.658 ${ }^{11}$ tiraram o título de eleitor. A relação estabelecida é de que cerca de $31 \%$ dos jovens brasilienses se alistaram voluntariamente, constatando queda relativa no alistamento eleitoral entre jovens. É interessante observar que o Distrito Federal encontrava-se acima da taxa de alistamento nacional nas eleições de 2002. Já em 2006, sua taxa encontrava-se não só significativamente abaixo da taxa nacional, mas como das outras UFs.

\section{Taxa de Alistamento Eleitoral}

38,7

31,6

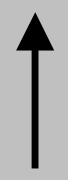

Brasília Brasil

2002

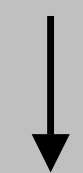

31,0

44,3

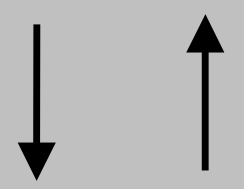

Brasília Brasil

\section{Os Partidos Políticos}

$\mathrm{Na}$ atual organização política brasileira, parte significativa da participação política institucional é inacessível a cidadãos comuns. Essa falta de acessibilidade não se deve a proibições formais, e sim pelas dificuldades efetivas de ingresso no

\footnotetext{
${ }^{11}$ Em consulta posterior ao site do TSE (20/3/2008), esse número foi informado como sendo 19.151, ainda menor.
} 
OPINIÃO PÚBLICA, Campinas, vol. 14, no 1, Junho, 2008, p.205-235.

campo político, em especial naquelas organizações que detêm o monopólio da representação política: os partidos.

De acordo com a legislação vigente desde a redemocratização, o Tribunal Superior Eleitoral permite que até partidos recém criados e com registro provisório participem das eleições, considerado por Jairo Nicolau (1996) como exemplo da abertura de nossa legislação político-eleitoral. Entretanto, antes de considerar que nosso sistema político é realmente aberto, há que se questionar: mesmo sendo juridicamente livre o ingresso em partidos políticos já existentes, mesmo sendo permitida a criação de novos partidos, será que quem quer participar ativamente da vida política do país se interessa por ingressar ou fundar partidos políticos? E, em caso positivo, os partidos políticos dão conta de responder às suas expectativas? Os novatos conseguem sobrepor-se às máquinas internas já montadas? Para quem é viável conseguir espaço numa competição já dada?

Para esboçar uma tentativa de resposta, é necessário resgatar o ideal de partido político, apresentado por Edmund Burke no final do século XVIII. Burke constatou que a existência de divergências no seio da sociedade (e de seus representantes) era uma realidade incontornável, e que tais divisões podiam ser canalizadas a fim de melhorar a organização do governo e o controle da monarquia. Assim, há uma função ideológica a ser desempenhada pelas agremiações políticas, elas surgem em função de divergências existentes na sociedade, em torno da organização política da sociedade, sobre os papéis do Estado, buscando, então, serem um canal organizado, institucional, dessas divergências.

Um pouco mais tarde na história, Max Weber também se debruçou sobre os partidos políticos quando estes já haviam conquistado um espaço mais central no campo político. Também para Weber, os partidos são organizações da sociedade civil, ou da sociedade política não estatal. Mas, além de seu caráter ideológico, Weber percebeu que nos sistemas políticos modernos os partidos podem assumir também a forma de uma organização para a disputa por cargos dentro do Estado. A vocação, o desejo, que em alguns tipos de partido toma a forma de influência, proposição e execução e projetos de sociedade, em outros toma a forma da ambição por cargos, de disputa por aparelhos administrativos.

Este é seu alerta para situações de representação profissional na política, que poderiam transformar os partidos em feudos de grupos de interesse, numa estrita divisão do trabalho em um mundo "racionalizado", em uma democracia de massas. A crescente geração de cargos administrativos, segundo Weber, não se daria exclusivamente pela burocratização da máquina pública, mas também pela ambição os partidos políticos. Afirma: "aos olhos de seus aderentes, os partidos aparecem, cada vez mais, como uma espécie de trampolim que lhes permitirá atingir esse objetivo essencial: garantir o futuro" (WEBER, 2002, p.62). Essa 
ambição não é intrínseca ao agente político, mas vem da organização burocrática. Algumas características dos partidos políticos são fundamentais para perceber sua estrutura de funcionamento:

1. Grupo especializado, coordenado por políticos profissionais dedicados exclusivamente à carreira política.

2. Monopólio da representação institucional de dois poderes (Chefe do Executivo e todos os membros do Legislativo) nas três esferas (União, Estado, Município).

Com essas duas características, podemos chegar ao que, de fato, os partidos políticos representam em termos de sua estrutura administrativa: um campo especializado com condutas, práticas, linguagens e códigos próprios, com acesso a espaços exclusivos e um ethos de atuação próprio. Em relação à presença de políticos profissionais na política institucional, essa questão deve ser talvez das mais conhecidas (com a polêmica dicotomia em viver para a política e viver da política). Por um lado, a profissionalização de lideranças significou o acesso de grupos não elitizados ao jogo político, pois grupos que não viviam de renda e títulos não teriam tempo ou condições físicas de interferir politicamente em decisões governamentais com uma jornada de trabalho de no mínimo 40 horas para ser cumprida, se não conseguissem mecanismos para se profissionalizar e atuarem exclusivamente em prol de suas causas. Por outro lado, entretanto, essa profissionalização abriu brechas para que o político profissional se descolasse de seu grupo de base social original. E, é necessário explicitar, os ocupantes destes cargos compõem não só uma elite, mas um campo com práticas e linguagens próprias (BOURDIEU, 1983). Para ingressar e ser reconhecido neste campo, é necessário adotar o comportamento de pares. E, historicamente, os pares iniciais eram aristocratas, somente depois se deu o ingresso paulatino de outros estratos sociais, que já encontravam uma estrutura de poder instaurada ${ }^{12}$.

Quanto ao monopólio da representação, encontramos aqui um dos aspectos mais interessantes da discussão. É sob esse aspecto que se pode observar que a disputa pelo acesso ao poder não é aberta a qualquer indivíduo ou a qualquer grupo. Um exemplo é apontado por Meneguello (1998), ao demonstrar a grande influência dos partidos com participação no governo na indicação dos ocupantes dos ministérios, ou seja, os cargos mais altos do Poder Executivo que não são decididos pelo voto direto. No acompanhamento que faz de seguidas composições de ministérios (de Tancredo Neves ao primeiro mandato de Fernando Henrique Cardoso), a autora mostra que aproximadamente dois terços dos titulares eram filiados a partidos políticos. Além deste indicador, é interessante avaliar também se mesmo os titulares que não são oficialmente quadros partidários não

\footnotetext{
12 Por exemplo, o surgimento da Câmara dos Lordes na Inglaterra, que ocorreu antes da Câmara dos Comuns e esta segunda câmara foi criada antes da aceitação do ingresso de não-proprietários na Casa.
} 
OPINIÃO PÚBLICA, Campinas, vol. 14, no 1, Junho, 2008, p.205-235.

correspondem de alguma maneira a concessões feitas aos partidos da base aliada do governo.

Uma brecha que é freqüentemente festejada por movimentos sociais como possibilidade de participação popular no Poder Executivo são os Conselhos. Entretanto, além de se questionar se, na verdade, esses conselhos atingem efetivamente "populares", é sabido até mesmo entre as organizações que estão inseridas nessas instâncias que seu poder é, realmente, muito pequeno, podendo até serem caracterizados como um espaço de cooptação e não de influência (INESC, 2006), dada sua reduzida capacidade real de determinar rumos de políticas implantadas pelo governo, e a visível capacidade do governo para pautar a agenda destas entidades.

Ainda em relação a este monopólio da representação política institucional, é preciso mencionar que o clímax das democracias liberais, o momento eleitoral, é ainda mais centralizado pelos partidos políticos. Por mais anunciado que seja que o futuro do país está nas mãos dos eleitores (conforme a campanha do TSE de estímulo ao voto nas eleições de 2006), é muito mais factível perceber que as mãos dos políticos, seus apoiadores, financiadores e grupos midiáticos detêm um acesso consideravelmente maior a esferas de decisão de grande impacto nas eleições, como definição de candidaturas, destinação do fundo partidário, formulação do programa de governo e construção da agenda (debates e embates). A distância entre o eleitor e candidato se faz presente em todos os momentos da campanha.

Em relação aos sistemas de representação política reais, Robert Michels afirma que, nas democracias de massa, a ampliação da participação política exige complexificação das estruturas organizativas, mas é exatamente a existência da organização que produz, necessária e inevitavelmente, tendências oligárquicas, ponto também registrado por Weber (2002).

Na visão de Michels, a participação na vida partidária adquire um aspecto de escala. A grande massa de eleitores constitui a base; sobre esta se sobrepõe a massa menor de militantes esporádicos de partidos, que representa talvez um décimo dos eleitores ou talvez até menos; em cima destes, por sua vez, vem o número muito menor dos membros que assistem regularmente às reuniões; depois vem o grupo de funcionários do partido; e, acima de tudo, o grupo de meia dúzia dos membros que constituem o comitê executivo, formado em parte pelas mesmas pessoas do grupo anterior. O poder efetivo aqui está na proporção inversa do número dos que acreditam que o exercem.

É importante frisar que esta análise de Michels é sobre partidos operários e sindicatos. Por mais que se pretenda estender a análise a qualquer organização, a análise empírica do autor se restringe a esses dois tipos específicos de associação civil. Outra ressalva ao trabalho de Michels é que trata a relação de poder como relação unilateral, por vezes monocausal e determinista (SARTI, 1996). 
Olhando sob outra perspectiva, além da estrutura organizativa, quando se elencam os critérios de avaliação dos partidos políticos, os mais comuns são (i) sua base social e (ii) sua orientação ideológica. Rapidamente, pode-se perceber as razões dos partidos políticos estarem perdendo sua legitimidade frente aos representados. Em termos de base social, em casos raros a composição social de um partido tem relação com a estratificação social da sociedade na qual ele está inserido. Os partidos de caráter classista, quando representam as classes mais baixas, ou abandonam suas características ou têm sérias dificuldades de ingresso no campo político, já que este também não foi estruturado de maneira a receber sua participação. Em termos de orientação ideológica, é notória certa "centralização" em termos de programa de governo (questões macroeconômicas), e temas polêmicos são sistematicamente omitidos de campanha, sendo deliberadamente postergados de enfrentamento ao longo dos mandatos.

\section{Prova de efetividade}

Como sustentado ao longo deste artigo, os partidos políticos não vêm cumprindo com as expectativas geradas desde sua criação (NORRIS, 1999). Michels acerta ao descrever um espaço fechado e hierarquizado de saberes e práticas, constituindo área em que, apenas teoricamente, qualquer um pode se preparar para chegar ao topo. Entretanto, mesmo sendo livre o acesso a partidos políticos e a fundação de novos, o monopólio da representação política acaba por excluir até mesmo grupos que buscam a organização partidária, mas não conseguem fazer com que sua voz seja ouvida.

De acordo com Giddens, a confiança das sociedades contemporâneas (em especial em sistemas peritos) não é comparável à confiança em sabedorias tradicionais (magos e feiticeiros), pois se baseia fundamentalmente na experiência, podendo ser rompida em caso de frustração. E, efetivamente, o acompanhamento real da política mais afasta do que motiva as pessoas para a participação, com notícias de corrupção em massa, discursos demagógicos, projetos de lei inúteis, barganhas fisiológicas, etc. (NORRIS, 1999).

Quem confia tem, em geral, uma atitude fundada no ceticismo metódico, ou seja, pode retirar a sua confiança a qualquer momento. O especialista estaria, assim, constantemente inclinado a reforçar o seu saber diante do leigo. Entretanto, como os partidos não vislumbram no horizonte próximo que seu monopólio da representação política institucional esteja ameaçado - afinal, eles mesmos produzem a legislação eleitoral - estamos diante de uma situação em que sua credibilidade vem caindo constantemente, assim como o percentual de eleitores 
OPINIÃO PÚBLICA, Campinas, vol. 14, no 1, Junho, 2008, p.205-235.

que se identifica com algum partido, sem que grandes transformações ocorram em nossa estrutura política.

Giddens aponta quatro reações de adaptação, ou absorção, realizadas pelos atores que interagem nesses cenários da modernidade reflexiva, classificadas como "conseqüências da modernidade": a aceitação pragmática, o otimismo sustentado, o pessimismo cínico (casos de experiências negativas) e o engajamento radical (GIDDENS, 1991, p.94). O pessimismo cínico é a resposta que mais encontra ressonância nas pesquisas de opinião que mensuram a credibilidade dos partidos políticos, seguido pela aceitação pragmática (NORRIS, 1999). É como se ninguém acreditasse que aquilo seja um sistema perito digno de confiança, mas na prática funciona como um, mesmo sem a crença, graças ao monopólio da representação política institucional.

É importante perceber que o afastamento dessas instituições políticas não significa um esgotamento da política em si, mas um esgotamento da capacidade de atração espontânea e voluntária que os partidos exercem sobre a população. A disposição para a ação política ou a crença nos regimes políticos democráticos não se traduz necessariamente em vontade de criar partidos ou de ingressar nos já existentes.

As pessoas percebem que a política impacta suas vidas (de maneira negativa, até), mas não conseguem ver um sistema político que as deixe impactar a política. Não se pode confundir essa rejeição crítica com simples alienação, que seria mascarar o contexto e causas dessa crítica. É importante perceber esse recusa aos partidos políticos não só como uma demanda por uma eventual e pontual Reforma Política, mas uma demanda por novos canais de intermediação entre a sociedade e o Estado.

É curioso perceber que a instituição Estado-nação vem sendo fortemente questionada, sob este paradigma da "pós-modernidade", do mundo "globalizado", enquanto os partidos políticos sobrevivem mais impunemente às análises de conjuntura. Um colega de Giddens, Ulrich Beck, faz uma reflexão a esse respeito:

"Os cientistas sociais têm dificuldades com o conceito de morte (...) Qualquer um que exclua o conceito de "morte institucional" se esquece de que estamos lidando com isso em toda parte: instituições zumbis que têm estado clinicamente mortas durante um longo tempo, mas não são capazes de morrer. Como exemplo, poderíamos considerar os partidos de classe sem classe" (BECK, 1997, p.54).

Esse diagnóstico poderia servir de base não só para que outros enfoques acadêmicos sejam dados à análise dos partidos políticos, mas também para que 
outras formas de fazer política, ou de se fazer presente na política, sejam também observadas com atenção e cuidado. A saída de determinados grupos sociais da atuação em partidos políticos não significa, de imediato, uma opção por não fazer política, mas apenas a opção de não fazer política de um modo específico. Por vezes, essa análise embute uma perspectiva de análise que sobrevaloriza o partido político em detrimento de outras organizações, a política institucional em detrimento de outros espaços de articulação política e os políticos profissionais em detrimento de outros atores políticos.

\section{Considerações Finais}

Alguns dos indícios reunidos neste artigo sugerem que não é a falta de informação que afasta os jovens da política no caso do Distrito Federal. Ao contrário, é justamente o conhecimento das atuais práticas políticas que traz uma rejeição "consciente" da política institucional. Com freqüência, são noticiadas pesquisas que mostram que uma grande maioria da população, qualquer que seja a faixa etária, não confia nos partidos políticos, na Câmara dos Deputados, no Senado Federal ou nas lideranças políticas em si. Antes de culpar as pessoas por um ceticismo exagerado, é necessário perguntar por que essa confiança vem se desfazendo. Esse artigo cumpre sua missão se conseguir inverter a lógica de interpretação. Talvez, o dado a ser estranhado nessas pesquisas seja os remanescentes que ainda afirmam confiar muito nessas instituições e em seus membros.

Na sociedade brasileira como um todo, e em outros países de regime democrático, há uma clara percepção popular de que as instituições democráticas não conseguiram viabilizar os ideais prometidos, seja de uma menor desigualdade social, seja de acesso popular a instâncias governamentais de decisão (NORRIS, 1999).

É interessante perceber que, no caso, o fenômeno da rejeição à política institucional ocorre intensamente com os jovens, pois estão ingressando agora como sujeitos na sociedade, ou seja, chegam estranhando um campo que parece muito longe, paralelo, que não Ihes diz respeito. Há uma recusa à transmissão de certa herança social, de um sistema que visivelmente não tem sabido ligar com a relação entre a população e seus representantes políticos.

Os altos índices educacionais, acesso à informação e proximidade com a política é que possibilitam a crítica e rejeição dessa forma de se fazer política, destes políticos e da maneira como estão estruturadas as atuais instituições políticas. 
OPINIÃO PÚBLICA, Campinas, vol. 14, no 1, Junho, 2008, p.205-235.

Em relação especificamente a como esse fenômeno é interpretado, quando o segmento em análise é a juventude, é interessante a observação de Helena Abramo:

"Houve sempre certa ressalva em relação à eficácia de suas ações [de jovens]: para os setores conservadores, a suspeita de baderna e radicalismo transgressor, para alguns setores da esquerda, a suspeita de alienação ou de radicalidade pequeno-burguesa inconseqüente" (ABRAMO, 1997, p.27).

Os dois enfoques mencionados na introdução deste artigo, que constroem "tipos ideais" de jovens de acordo com suas visões de mundo, voltam a influenciar a análise que se faz do comportamento político dos jovens reais. O fenômeno do baixo alistamento eleitoral é visto como "culpa" e "traição" por analistas externos que almejam ver na juventude uma vanguarda engajada na promoção de uma nova era, enquanto outros vêem negativamente o esvaziamento dos partidos políticos e simultaneamente o surgimento expressivo de pequenas organizações políticas, menos hierarquizadas e com possibilidade de maior autonomia de ação para seus membros.

A única exceção nessa análise é, na verdade, a mais negativa. O fenômeno da não-participação eleitoral só não é um problema na visão dos elitistas democráticos, na medida em que a participação, de maneira geral, é dispensável. Huntington, com sua preocupação com a manutenção da ordem, escreveu que "o funcionamento eficaz de um sistema democrático requer, em geral, um nível de apatia e de não-participação por parte de determinadas pessoas e grupos" (HUNTINGTON, 1975, p.114), em sua percepção de que pessoas participativas são um risco maior para os sistemas políticos que pessoas apáticas, pois geram demandas sociais e tencionam seus líderes e governantes.

Entretanto, a idéia de que a apatia eleitoral, na verdade, represente a conformação e satisfação com os sistemas políticos em vigor é freqüentemente questionada dentro da teoria política:

"Mobilização extra-eleitoral e apatia são respostas diferentes - a primeira indica a esperança de mudança, enquanto a segunda revela ceticismo -, mas ambas se opõem à adesão confiante no sistema político que o bom funcionamento da representação deveria disseminar" (MIGUEL, 2005, p.32).

Os jovens pesquisados não se sentem parte da política institucional, o que não significa, de modo algum, que não sejam interessados por política. Há outra visão da política em jogo: a da política do cotidiano, de pequenas organizações, de 
grupos informais, especialmente ligados à área cultural. Esse dado indica uma descrença muito forte nos políticos profissionais, e uma busca de outros espaços para se acreditar no agir político. O voto deixou de ser percebido como esse espaço. É simbólico que esse recado venha da primeira geração democrata da nova república, da juventude de Brasília, da capital política do país.

\section{Referências bibliográficas}

ABRAMO, H. Cenas juvenis: punks e darks no espetáculo urbano. São Paulo: Scritta, 1994. "Considerações sobre a tematização social da juventude no Brasil". Revista Brasileira de Educação, n 5/6, Juventude e Contemporaneidade. p. 25-36, 1997.

ABRAMO, H. e VENTURI, G. “Juventude, política e cultura”. São Paulo: Fundação Perseu Abramo. Revista Teoria e Debate, n 45, 2000.

ABRAMO, H. e BRANCO, P. P. M. (Orgs.). Retratos da Juventude Brasileira: análises de uma pesquisa nacional. São Paulo: Perseu Abramo, 2005.

ABRAMOVAY, M.; RUA, M. G. et al. Gangues, galeras, chegados e rappers. Rio de Janeiro: Garamond, 1999.

ALTHUSSER, L. A favor de Marx. Rio de Janeiro: Jorge Zahar, 1965.

BOURDIEU, P. Questões de sociologia. Rio de Janeiro, Marco Zero, 1983.

CARDOSO, I. "A geração dos anos de 1960: o peso de uma herança". Tempo Social. São Paulo, vol. 17, n. ${ }^{\circ} 2,2005$.

CICONELLO, A. (org). Relatório do Seminário: Novas estratégias para ampliar a democracia e a participação.INESC, 2006.

COSTA, O. Relatório Regional do DF. In: IBASE/PÓLIS. Juventude Brasileira e Democracia participação, esferas e políticas públicas. Rio de Janeiro, 2005.

DOWNS, A. An economic Theory of Democracy. New York: Harper Collins Publishers, 1957.

FORACCHI, M. O estudante e a transformação da sociedade brasileira. São Paulo: Companhia Editora Nacional, 1965. 
OPINIÃO PÚBLICA, Campinas, vol. 14, no 1, Junho, 2008, p.205-235.

A juventude na sociedade moderna. São Paulo: Livraria Pioneira, 1972..

FREIRE, A., \& Magalhães, P. A abstenção eleitoral em Portugal. Lisboa: ICS, 2002.

GIDDENS, A. As conseqüências da modernidade. São Paulo: UNESP, 1991.

GIDDENS, A. e BECK, U.; LASH, S. Modernização reflexiva: política, tradição e estética na ordem social moderna. São Paulo: UNESP, 1997.

GOFFMAN, E. A Representação do Eu na Vida Cotidiana. Petrópolis: Vozes, 1975.

HUNTINGTON, S. The Crisis of Democracy. New York: University Press, 1975.

IBASE/PÓLIS. Juventude Brasileira e Democracia - participação, esferas e políticas públicas relatório final. Rio de Janeiro, 2005.

INSTITUTO BRASILEIRO DE GEOGRAFIA E ESTATÍSTICA. Pesquisa nacional de amostra por domicílios, 2005. Rio de Janeiro: IBGE, 2006.

LIPSET, S. El hombre político: las bases sociales de la política. Madrid: Tecnos, 1987.

MANNHEIM, K. O problema da juventude na sociedade moderna. In: Sociologia da Juventude, I. Rio de Janeiro: Zahar Editores, 1968.

O problema sociológico das gerações. In: FORACCHI, M. M. (org.) Karl Mannheim: Sociologia. São Paulo: Ática, 1982.

MELUCCI, A. "Juventude, tempo e movimentos sociais". Revista Brasileira de EducaçãoANPED - Juventude e Contemporaneidade. n5 e 6 , p. 5-14, 1997.

MENEGUELLO, R. Partidos e Governos no Brasil Contemporâneo (1985-1998). Rio de Janeiro: Paz e Terra, 1998.

MICHELS, R. Sociologia dos Partidos Políticos. Brasília: Editora da Universidade de Brasília. Coleção Pensamento Político, n 53, 1982.

MIGUEL, L. F. "Liberdade ou felicidade? A auto-realização humana em Marx, Gorz e Elster". Filosofia Política, Porto Alegre. n 4. p. 176-210, 1999. 
"Impasses da accountability: dilemas e alternativas da representação política". Revista de Sociologia e Política, n² 25. Curitiba, p. 25-38, 2005.

MÜLLER, E. Novas juventudes, velhos conceitos: considerações sobre a noção de cultura juvenil. Paper apresentado no VII Encontro de Ciências Sociais do CFCH/UFPE. Recife, 2004.

. A idade do olhar: implicações da condição etária do/a pesquisador/a de juventudes. In: 30 Encontro ANPOCS, 2006, Caxambu. 30 Encontro ANPOCS, 2006.

MÜXEL, A. “Jovens dos anos 90: à procura de uma política sem 'rótulos'. Revista Brasileira de Educação, no 5 e 6. São Paulo: ANPED, p. 151-166, 1997.

NORRIS, P. Critical citizens: Global support for democratic government. Oxford: Oxford University Press, 1999.

NICOLAU, J. Multipartidarismo e Democracia: um estudo sobre o sistema partidário brasileiro (1985-94). Rio de Janeiro: FGV, 1996.

NUNES, B. Brasília, a fantasia corporificada. Brasília: Paralelo 15, 2004.

RAMOS, P. N. Alheamento Decisório Eleitoral: o significado de votos em branco, votos nulos e abstenções eleitorais. Monografia, Instituto de Ciência Política da UnB, 2001.

SARTI, I. "A utopia de Michels e a democracia partidária em perspectiva". Revista Brasileira de Ciências Sociais, v. 30, n. 11, p. 129-137, 1996.

SARTORI, G. A teoria da democracia revisitada, vol. 1. São Paulo: Ática, 1994.

WAISELFISZ, J. J. Relatório de desenvolvimento juvenil 2003. Brasília: UNESCO, 2004.

WEBER, M. Ciência e política: Duas vocações. In: Ensaios de Sociologia. Rio de Janeiro: LTC, 2002.

WOLFF, R. P. A miséria do liberalismo. Rio de Janeiro: Paz e Terra, 1968.

Renata Florentino - renataffsantos@yahoo.com.br

Recebido para publicação em novembro de 2007.

Aprovado para publicação em fevereiro de 2008. 